\title{
迹通 \\ Earnings Management in Malaysian Companies during the Global Financial Crisis and the Coincidental Effect of IFRS Adoption
}

\author{
Abdullah Mohammed Ayedh ${ }^{1}$, A. H. Fatima ${ }^{2}$, and Muslim Har Sani Mohammad ${ }^{3}$
}

\begin{abstract}
Purpose: This research examines earnings management (EM) behavior during the 2008 financial crisis in Malaysia. Both magnitude and direction of EM are studied and compared with EM during the pre-crisis period. In the case of Malaysia, the Malaysian Accounting Standards Board (MASB) adopted the international accounting standards, i.e. the International Financial Reporting Standards (IFRS) just two years prior to the crisis period. These standards could have some influence on EM during the global financial crisis period in Malaysia, thus are also taken into consideration in this study.
\end{abstract}

Methodology: Data were collected from the Bloomberg database, and the proxy for EM was discretionary accruals (DA), which were measured using two models, namely the modified Jones model by Dechow et al. (1995) and the modified Jones model by Kothari et al. (2005).

Findings: The empirical findings of paired-sample T-tests for 1,189 firm-years revealed that EM practices in the Malaysian companies were income decreasing during the crisis period (2008 and 2009), compared to the pre-crisis period (2005 and 2006) when the practices were income-increasing. The findings of this study are consistent with big bath theory. Furthermore, simple multivariate regressions support the findings that EM is significantly more negative or less positive during the crisis period. Nevertheless, the adoption of IFRS seems to suggest some deterring influence on EM practices of Malaysian companies.

Research Limitation: The limitation of this study is that it uses rudimentary measures to proxy crisis period and IFRS in the regressions. Moreover, this study includes only one control variable (company size).

Practical implication: the findings of this study would inspire more research on EM during abnormal periods, such as a financial crisis period, whilst taking accounting regulation into consideration, particularly in Asian countries. In addition, the policy makers might give more attention to ensure the enhancement of the adherence of IFRS adoption.

Originality: The paper addressed a practical issue of EM during crisis period using two different proxies. In addition, the paper applied the integrated variable CriIFRS, which reflects the crisis period, taking into consideration IFRS adoption. Albeit preliminary, this is considered the main originality and novelty of the current study.

JEL classification: M41, K22.

Keywords: Earnings management, Financial crisis, accounting standards, Malaysia.

\footnotetext{
${ }^{1}$ Faculty of Economics and Muamalat, Islamic Science University of Malaysia, Bandar Baru Nilai, 78100 Nilai, Negeri Sembilan, Malaysia

${ }^{2}$ Faculty Economics and Management Sciences, International Islamic University Malaysia, 53100 Kuala Lumpur, Malaysia

${ }^{3}$ Faculty Economics and Management Sciences, International Islamic University Malaysia, 53100 Kuala

Lumpur, Malaysia
} 


\section{INTRODUCTION}

Earnings management (EM) is an issue of concern by stakeholders and regulators in numerous countries across the globe. Their concern is because EM is associated with managers behaving opportunistically, consequently misreporting financial statement figures, in particular earnings. In order to manage earnings, managers apply accounting policies to change accounting estimates and manage accruals recognition, i.e. 'management of accounting choice'. On the other hand, they could make various operating decisions affecting real transactions related to cash flows, i.e. 'economic earnings management' (DeAngelo, 1986; Healy and Wahlen, 1999; Dechow and Skinner, 2000; Yoon and Miller, 2002; Peasnell, Pope and Young, 2005; Mohd-Saleh, Mohd-Iskandar and Rahmat, 2005; Aljifri, 2007). Generally, managers are motivated to manage earnings due to various market pressures, incentives of self-preservation and to avoid breaching contractual agreements (Watts and Zimmerman, 1978; Healy and Wahlen, 1999). However, during a financial crisis, managers may have stronger incentives to manage earnings (Chia, Lapsley and Lee, 2007), as explained below.

The global financial crisis originated in the United States of America (US), perpetrated by some of its largest financial institutions (Rudd, 2009). Crotty (2009) described this financial crisis as "the worst financial crisis since the Great Depression" (p. 563). According to Crotty (2009), the severity of the crisis, "pushed the global economy to the brink of depression" (p. 564). Similarly, Rudd (2009) has referred to the crisis as "one of the greatest assaults on global economic stability" (p. 20) as it caused a "deep slump in global trade and global recession" (Goh and Lim, 2010; pp. 1). Therefore, the ripples of the financial crisis in the US spread far and wide, negatively affecting the global economy and stock markets all over the world (IMF Working Paper, 2009; KPMG Report, 2009). Eventually, the Asian economies were also affected by the global financial crisis, including the Malaysian economy (International Monetary Fund Report, 2008, 2009 and 2010).

The consequences of the crisis in the US was felt in the Malaysian economy in 2008, with adverse effects on the trade and financial channels (Goh and Lim, 2010). In the fourth quarter of 2008, the Malaysian Gross Domestic Product (GDP) contracted by 12 percent and continued to deflate in 2009 (International Monetary Fund Reports, 2008, 2009, and 2010; Institute of Strategic and International Studies Malaysia Report, 2009). During the crisis (early 2009) exports plummeted 28 percent in comparison to the year before (Goh and Lim, 2010). Moreover, foreign direct investments fell 17 percent in 2008 compared to 2007, whereas there was an increase in direct investments abroad by Malaysian companies (Goh and Lim, 2010). This indicated that funds were flowing out of Malaysia during the crisis, which consequently affected Malaysia's real economy in terms of loss in industrial production and jobs (Goh and Lim, 2010). The World Bank Report (2009) reported that approximately 120,000 workers were retrenched in Malaysia (Goh and Lim, 2010). Furthermore, during the crisis period, the Malaysian stock market had increased volatility and leverage (Angabini and Wasiuzzaman, 2011). Based on the above, managers in Malaysian companies may have stronger motives to manage earnings during the crisis, to retain investors while the stock market was volatile, as well as to avoid breaching debt covenants as leverage increased. These motives may be fuelled by the pressure to ensure the survival of their company, consequently saving the jobs of their employees.

On the contrary, according to International statistics (IMF Working Paper, 2009; Institute of Strategic and International Studies Malaysia Report, 2009), the Asian financial 
crisis was considered more severe than the global financial crisis on Asia. Hence Asia was less affected by the global financial crisis compared to other continents. On a different note, literature (Chia et al., 2007; Rusmin, Scully and Tower, 2013) indicates that companies tend to use income decreasing EM during a period of crisis. Such practices of using discretionary accruals to intentionally reduce earnings is consistent with 'big bath theory'. Therefore, during the global financial crisis period, Malaysian companies may also resort to the reverse, that is by managing earnings downwards (income decreasing) instead of upwards (income increasing). Based on the above, there are a number of possibilities on EM by Malaysian companies during the global financial crisis: practising more EM, adopting more income increasing EM practices or employing more income-decreasing EM activities. However, since there is a dearth of literature on EM by Malaysian companies during the global financial crisis, the practices of managers in Malaysia during the recent crisis warrants research.

Furthermore, coincidentally just two years prior to the crisis, the International Financial Reporting Standards (IFRS) were adopted in Malaysia. Malaysia is a Commonwealth country; therefore, its Companies Act was influenced by the Companies Act of the United Kingdom (UK), and the annual reports of Malaysian listed companies have always been published in English. In 1975, Malaysia became a member of the International Accounting Standards Committee (IASC). Thus International Accounting Standards (IAS) predominantly influenced Malaysian accounting standards (MICPA, 2007). Then, the Financial Reporting Act was enacted in 1997. Under the purview of this Act, the Malaysian Accounting Standards Board (MASB) was established (MICPA, 2007). The MASB continued to adopt IAS, but also issued local standards. However, in 2006 the MASB adopted the International Financial Reporting Standards (IFRS) issued by the International Accounting Standards Board (IASB) ${ }^{4}$ with the aim of full convergence to International Financial Reporting Standards (IFRS) in 2012. Therefore, although Malaysian accounting standards were in line with international standards since 1975, it was only in 2006 that IFRS was adopted. The IFRS are aimed towards improving financial reporting quality. Hence these standards may possibly hinder opportunistic practices of EM in Malaysia during the crisis.

Therefore, the objective of this paper is to measure EM in Malaysia during the financial crisis period, which is a crisis described by Rudd (2009) as one of the greatest assaults to the global economy. In order to better comprehend the EM that takes place, this study not only measures the magnitude of EM through absolute discretionary accruals, it also analyses the direction of EM using positive and negative discretionary accruals. Furthermore, although managers may be motivated to manage earnings during a critical period of crisis, it just so happens that Malaysia adopted the IFRS prior to the occurrence of the global financial crisis. Hence, there is a possibility that the adoption of IFRS could dampen EM practices, or it could be that the IFRS had little effect on EM practices. Hence, this paper studies EM in a crisis period subsequent to Malaysian companies adopting IFRS.

Although it is logical to expect more EM practices during crisis periods, EM in Malaysia during the crisis has to be compared with EM before the crisis. Therefore, EM by Malaysian companies in a non-crisis period is used to gauge the severity of EM during the crisis period. As explained above, the global financial crisis had a detrimental effect on the Malaysian economy. During this period, Malaysian companies may turn to EM to prolong their survival or take a 'big bath'. Therefore, this study would be useful to regulators and stakeholders in Malaysia, to discover the magnitude and type (i.e. positive or negative) of EM that is practised by Malaysian listed companies during a financial crisis period. Moreover,

\footnotetext{
${ }^{4}$ The International Accounting Standards Committee (IASC) was rebranded into the International Accounting Standards Board (IASB) in 2001.
} 
accounting regulators may also be interested to find out, since the IFRS was adopted recently before the crisis, could the adoption of IFRS have had a possible impact on EM during the crisis period.

The remainder of the paper is organised as follows: Section two reviews relevant prior studies. Section three presents the hypotheses and research method used in the study, and section four discusses the main findings. The final section concludes the study with the implications of the findings and corresponding limitations, as well as some recommendations for future studies.

\section{LITERATURE REVIEW}

In the present business environment, the pressures, opportunities and motivations to practice EM are as great as any time in history (Peecher et al., 2007). Based on the literature, the motivations of managers to manipulate reported earnings depend on the orientation of the managers and the surrounding business environment. Since Watts and Zimmerman (1978) proposed a number of motives for management behaviour (i.e. bonus plan, debt-equity and political cost hypotheses), studies on EM have been carried out in various developed and developing countries (Alves, 2012; Naidu and Patel, 2013; Goel, 2016; Abbadi et al., 2016). However, the following review of the literature will only focus on relevant recent studies pertaining to EM, financial crisis and International Financial Reporting Standards (IFRS) adoption. Specifically, the literature review starts with a discussion on studies that investigated EM during the global financial crisis. Then, the review proceeds with the recent literature on big bath theory, followed by studies on IFRS adoption and EM. Finally, the literature focuses on relevant EM studies in Malaysia.

Iatridis and Dimitras (2013), as well as Filip and Raffournier (2014), investigated EM in Europe during the financial crisis. The former's sample focused on listed companies in 5 European countries, namely Greece, Ireland, Italy, Portugal and Spain; whereas the latter's sample comprised of 16 countries in Europe. Iatridis and Dimitras'study (2013) used discretionary accruals to measure EM, and their results reveal that Portugal, Italy and Greece engaged in more EM. In contrast, there was evidence of EM in Ireland. However, there were mixed results on EM in Spain. Filip and Raffournier (2014) also used discretionary accruals measure EM, along with income smoothing measures. Their study's period was from 2006 2009, which encompasses periods subsequent to European companies adopting IFRS. Based on their measures of EM, Filip and Raffournier (2014) found that EM significantly decreased during the crisis years, in terms of magnitude. This finding of lower EM applied to both positive and negative discretionary accruals. Cimini (2015) also studied EM in Europe but for a longer period of 2006 - 2012, compared to Filip and Raffournier (2014). Cimini (2015) had similar findings, where there was a decrease in abnormal accruals during the crisis in the majority of European countries studied.

EM during the 2008 financial crisis was also studied in other parts of the world, for example by Mollik, Mir and Bepari (2013) in Australia, Da Silva et al. (2014) in Brazil and AlGhazzawi and Alsoboa (2016) in Jordan. Discretionary accruals were used as a measure of EM in these studies. Mollik et al.'s (2013) and Da Silva et al.'s (2014) studies also analysed the direction of EM, i.e. either positive or negative. The findings of the former (Mollik et al., 2013) indicated a tendency of Australian managers to manage earnings downwards during the financial crisis (2008-2009). Similarly, the latter (Da Silva et al., 2014) revealed that there was generally more negative EM during the crisis period. On the other hand, Al-Ghazzawi and Alsoboa (2016) had results similar to the European studies (Filip and Raffournier, 2014; 
Cimini, 2015), where there was reduced EM during the crisis period. Since the studies on EM during financial crisis mention EM downwards or negative EM, these could be deemed as 'big bath'. Thus, recent big bath literature is briefly reviewed next.

In general, the big bath theory is referred to in CEO turnover literature (Nieken and Sliwka, 2015; Jordan and Clark, 2015; Riyadi, Utami, Nugroho, 2018). The main argument of this literature is that new CEOs would depress the current year's earnings (big bath). This is because part of the poor performance could be justified by past years' management, whilst planning for 'enhanced future profitability' (Jordan and Clark, 2015; Rusmin et al., 2013). Some literature finds evidence of big bath being practised by new CEOs (Nieken and Sliwka, 2015; Riyadi et al., 2018) regardless of routine or non-routine CEO change (Riyadi et al., 2018). On the other hand, Jordan and Clark (2015) did not find any evidence of manipulative reporting by new CEOs. In addition to CEO turnover, financially distressed firms, including those during a financial crisis would practice big bath (Habib, Bhuiyan and Islam, 2011; Rusmin et al., 2013) as evidenced in the EM literature above.

Next, this paragraph briefly reviews recent literature on EM and the adoption of IFRS in developing countries. This is because the context of developing countries would be more relevant to the Malaysian scenario. Al-Ghazzawi and Alsoboa (2016) in Jordan used the modified Jones model to measure EM. Overall, their results suggest that the adoption of international standards did not prevent EM in Jordanian companies. Similarly, Rathke et al. (2016) investigated EM in Latin American countries after IFRS adoption. They also used the modified Jones model to calculate EM. Their results suggest that EM is still high in Latin American countries compared to Anglo-Saxon and Continental European countries. Rathke et al. (2016) explained that this could be because the local setting could influence the application of IFRS in each country.

Finally, focusing on the country of study, Malaysia, there are numerous studies on EM in Malaysia (Md Nasir et al., 2018; Wasiuzzaman, Sahafzadeh and Nejad, 2018). Md Nasir et al. (2018) examined whether Malaysian companies that were charged with financial statement fraud used real EM or accruals EM prior to the fraud year; whereas Wasiuzzaman et al. (2018) investigated EM in 15 different industries in Malaysia. The former's sample was 65 fraud and 65 non-fraud companies from 2001 to 2008. On the other hand, the latter's sample comprised 538 firms from 2005 to 2011. Wasiuzzaman et al. (2018) found EM practices in their sample of Malaysian companies, but the motives for EM differed across the various industries. Md Nasir et al.'s study provides evidence that financial statement fraud firms tend to use accruals EM rather than real EM prior to the fraud year.

In general, the majority of the EM research in Malaysia study the effect of corporate governance (Mohamad, Abdul Rashid and Shawtari, 2012) and its components on EM. Mohamad et al.'s (2012) paper specifically focused on the effectiveness of board of directors (BoD) on EM, after transformation initiatives to improve governance, in Government Linked Companies (GLCs). Their study found that only boards meetings and leadership structure had some impact on curbing EM practices. Wan Mohamad et al.'s (2016) paper also tested audit committee (AC) and ethnic diversity in addition to BoD. However, their study was limited to the manufacturing sector, and they found that all three variables were positively associated with EM. Similarly, Al-Absy et al. (2018) found that accounting expertise on AC did not hinder EM practices in 143 listed companies from 2013 until 2015. They suggested that AC members may not be truly independent. Other studies researched women directors (Nahar and $\mathrm{Ku}$ Ismail, 2016) and ownership, such as family ownership (Nahar and Ku Ismail, 2016) or ownership concentration (Al-Jaifi, 2016) and EM. Both studies used listed companies as their sample. Nahar and Ku Ismail's (2016) findings reveal that women directors on AC leads 
to income decreasing EM. However, family ownership did not moderate the association between women directors on BoD or on AC with EM. On the other hand, Al-Jaifi's (2016) results suggest that as Malaysian companies have high ownership concentration, EM is informative to the market.

Although there are several studies on EM in the Malaysian context, the literature on EM during the financial crisis period is limited. Only two studies were found on EM during and after the Asian financial crisis in 1997, respectively. The first was by Saleh and Ahmed (2005), who examined EM behaviour whilst negotiating with lenders during the 1997 financial crisis. Just like other literature (Da Silva et al., 2014) on the financial crisis period, Saleh and Ahmed (2005) also found that EM was significantly more negative during the crisis period. The second study was by Masruki and Azizan (2012), who studied 30 listed companies on the Main Board of Bursa Malaysia for the period 1999 until 2002. They used cash from operations to group their sample into 10 portfolios. Their results indicated that poor performing firms used income increasing EM, whereas companies that were performing exceptionally well did the reverse and employed income decreasing EM practices. In addition to studies on the Asian financial crisis period of 1997, there was only one study found on the global financial crisis of 2008, which incorporated Malaysian data as part of its study. Rusmin et al. (2013) investigated 328 listed transportation companies across 6 Asian countries. The countries were China, Hong Kong, India, Japan, Korea, Malaysia and Singapore. Rusmin et al.'s (2013) findings support the big bath theory where transportation firms used less aggressive income increasing EM, instead managers of these companies used income decreasing EM activities during the global financial crisis period.

Based on the review of the literature, there is a dearth of studies on EM practices during a financial crisis, specifically in Malaysia. In addition to filling the gap in the literature in Malaysia in studying the 2008 financial crisis, this research analyses both the direction and magnitude of EM before and during the financial crises using both modified Jones models by Dechow et al. (1995) and Kothari et al. (2005). Furthermore, the study takes into consideration the introduction of IFRS in Malaysia just prior to the crisis period.

\section{METHODOLOGY}

\subsection{Hypotheses}

It is quite logical to expect that under the pressure of a financial crisis, companies may want to portray a better reflection of their financial performance to stakeholders by utilising upwards $\mathrm{EM}^{5}$ practices. However, the review of the literature reveals that the prominent theory during a crisis is 'big bath theory'.

Healy (1985) proposes, in the 'big bath theory', that managers who are unable to meet their earnings' targets in the current year, hence not attain a bonus, would deflate earnings, i.e. EM downwards. By reducing the earnings figure, i.e. 'big bath', positive earnings figure would be lower (less positive earnings), or there would be greater losses (more negative earnings). This 'savings' in earnings could be utilised in the following year to ensure that a bonus is attained subsequently. Similarly, the literature shows that under exceptional circumstances, such as CEO turnover or financial crisis period, earnings tend to be more negative or income decreasing (Habib et al., 2011; Da Silva et al., 2014; Cimini, 2015; Riyadi et al., 2018), thus supporting the big bath theory.

\footnotetext{
${ }^{5}$ EM upwards and downwards are proxied by positive and negative discretionary accruals, respectively. EM upwards and downwards are also known as income increasing and income decreasing RM, respectively.
} 
During the global financial crisis, it is conceivable that the financial performance, in particular earnings, of Malaysian companies would be lower, and this would be expected by shareholders and stakeholders. Therefore, managers in Malaysian companies may also take advantage of the crisis period, and use negative discretionary accruals to lower earnings further, thus in line with the big bath theory.

Prior studies use absolute discretionary accruals (ADA) to measure EM. However, ADA measures the magnitude of EM, hence indicates whether there is more or less EM in a certain period; it would not indicate whether the EM practices are income increasing or income decreasing (more explanation is provided in the next section). In order to test whether big bath theory was supported, the direction of the EM practices would be needed. Therefore, two hypotheses are framed in this study, one which focuses on the magnitude of EM, and the second considers the direction of EM practices.

In order to test whether there is more EM during the crisis period, a comparison has to be made with a pre-crisis period to determine if the difference is significant. A significantly higher ADA in the crisis period would indicate that there was more EM during the crisis period than before. However, the European studies (Filip and Raffournier, 2014; Cimini, 2015) of the global financial crisis found that there was significantly less EM during the crisis period. Nevertheless, these studies provide evidence that there is a significant difference in the magnitude of EM during the crisis period compared to the pre-crisis period. Hence, this is hypothesised in the following hypothesis.

\section{H1: There is a significant difference between earnings management practices (in terms of magnitude) in Malaysia during and before the 2008 global financial crisis.}

Then, in reference to the big bath theory and the discussion above, managers would practice EM downwards, i.e. 'take a bath' during the crisis period. This would be reflected in positive discretionary accruals (DA) of smaller values (less positive EM) and larger negative values for negative DA (more negative) during the crisis period than pre-crisis. Smaller values of positive DA and larger negative DA would mean EM practices were less positive and more negative, respectively. Thus, the following hypothesis:

H2: Earnings management practices are significantly more negative or less positive in Malaysia during the 2008 global financial crisis compared to before the crisis.

Earnings management is usually practised within the scope that is allowable by accounting standards. Hence, the analyses of EM during the global financial crisis period cannot be devoid of considering the accounting standards, particularly when IFRS were just adopted two years prior to the crisis period. Institutional theory, specifically coercive isomorphism, posits that regulation would put pressure on the companies to comply with the requirements of that specific regulation. Similarly, the IFRS has been made mandatory to Malaysian listed companies by virtue of the Financial Reporting Act 1997, as explained above. Therefore, it is perceived that IFRS would possibly deter EM activities. However, the empirical evidence seems to be mixed, whereby some literature (Ahmed et al. 2013; Li et al., 2014) found EM increased subsequent to the adoption of IFRS. The reason is that the standards allow more subjectivity and professional judgement being principal-based, which enables EM opportunities. On the other hand, literature in developing countries (Alsoboa, 2016; Rathke, 2016) did not find evidence to suggest that IFRS reduced EM practices in Jordan and Latin American countries, respectively. In contrast, European studies found that 
EM reduced after IFRS adoption in most countries, even during the global financial crisis (Filip and Raffournier, 2014). As the prior studies provide mixed findings, the following hypothesis is non-directional.

H3: IFRS would have a significant influence on earnings management practices during the 2008 global financial crisis.

Subsequent to forming hypotheses, the following sections describe the sample selection.

\subsection{Sample selection}

At the end of 2009, there were 863 firms listed on Bursa Malaysia. The financial sector was excluded from the sample due to their unique business activities, and different regulatory requirements (Abdullah and Mohd-Nasir, 2004; Abdul-Rahman and Mohd-Ali, 2006) in Malaysia. Moreover, the study excluded those firms with missing observations for any variable in the model during the period 2004-2009. Therefore, the final sample was 1,170 firm-years from six sectors. The sample is equivalent to 234 listed companies' data for five years, which means that it is balanced panel data. After determining the sample, a matched set of non-sample companies were used to compute the coefficient parameters for each sector.

The data of EM components (total asset, cash flow from operations, net income, revenue, account receivable, and gross fixed asset) were used to calculate discretionary accruals (DA) and absolute discretionary accruals (ADA). Data was collected for the years 2004 to 2009 from the Bloomberg database in order to calculate DA and ADA for the sample periods 2005, 2006, 2008 and 2009. The years 2005 and 2006 were selected as 'pre-crisis period'. This was because a pre-crisis period was needed as a comparison for the crisis period, and these two years were the closest to the crisis period. The year 2007 was excluded from the study to ensure a clear distinction between the pre-crisis period and crisis period, which was in 2008 and 2009. As mentioned in the introduction of this paper, the Malaysian GDP contracted in 2008 and continued to do so in 2009. However, the GDP recovered by 7 percent in 2010 (International Monetary Fund Reports, 2008, 2009, and 2010; Institute of Strategic and International Studies Malaysia Report, 2009). Therefore, in the case of Malaysia, the financial crisis period was, basically, restricted to a two-year period of 2008 and 2009.

\subsection{Model and tests}

This study uses DA to measure EM, as in several prior studies (Kothari et al., 2005; Peasnell et al., 2005; Abdul-Rahman and Mohd-Ali, 2006; Aljifri, 2007; Siregar and Utama, 2008; AlThuneibat et al., 2011). This study applies two models to decompose total accruals into discretionary (unexpected or abnormal) accruals and non-discretionary (expected or normal) accruals. The non-discretionary accruals were computed by regressing total accruals and the changes in revenue during the year, firm's property, plant and equipment, and current period lag and cash flow from operations. The unexpected or abnormal portion of total accruals from this equation is discretionary accruals.

The first model is the modified Jones (1991) model by Dechow et al. (1995). The second model is a modified version of the modified Jones model with return on assets by Kothari et al. (2005). The latter (Kothari et al., 2005) argued that adding performance (return 
on asset) to DA helped overcome the misspecification issue caused by using the modified Jones model by Dechow et al. (1995).

In order to derive DA based on these two models, several requirements must be met. Firstly, to compute DA for the particular year (t), data (e.g. total assets, change in revenue and change in account receivables) for the year before (t-1) should be available. Secondly, DA coefficient for each industry must be computed from at least 8 to 10 non-sample companies from the same sector. In other words, industries with less than ten observations should not be included in the generation of DA (Peasnell et al., 2005; Bartov et al., 2001; Klein, 2002; Aljifri, 2007).

Finally, DA is the difference between non-discretionary accruals and total accruals. The modified Jones model (Dechow et al., 1995) is presented in Equation (1), whereas the second model applied in this study by Kothari et al. (2005) is shown in Equation (2).

$$
\begin{aligned}
\mathrm{DA}_{\mathrm{itj}}= & \mathrm{TA}_{\mathrm{itj}} / \mathrm{A}_{\mathrm{itj}-1}-\left[\boldsymbol{\beta}_{0}\left(1 / \mathrm{A}_{\mathrm{itj}-1}\right)+\boldsymbol{\beta}_{1}\left(\Delta \mathrm{REV}_{\mathrm{itj}}-\Delta \mathrm{REC}_{\mathrm{itj}} / \mathrm{A}_{\mathrm{itj}-1}\right)+\right. \\
& \left.\boldsymbol{\beta}_{2}\left(\mathrm{PPE}_{\mathrm{itj}} / \mathrm{A}_{\mathrm{itj}-1}\right)\right]
\end{aligned}
$$

$$
\begin{aligned}
\mathrm{DA}_{\mathrm{itj}}= & \mathrm{TA}_{\mathrm{itj}} / \mathrm{A}_{\mathrm{itj}-1}-\left[\boldsymbol{\beta}_{0}\left(1 / \mathrm{A}_{\mathrm{itj}-1}\right)+\boldsymbol{\beta}_{1}\left(\Delta \mathrm{REV}_{\mathrm{itj}}-\Delta \mathrm{REC}_{\mathrm{itj}} / \mathrm{A}_{\mathrm{itj}-1}\right)+\right. \\
& \left.\boldsymbol{\beta}_{2}\left(\mathrm{PPE}_{\mathrm{itj}} / \mathrm{A}_{\mathrm{itj}-1}\right)+\boldsymbol{\beta}_{3} \mathrm{ROA}_{\mathrm{itj}}\right]
\end{aligned}
$$

Where:

$A_{i t j-1}=$ Total assets in year ${ }_{t-1}$ for firm $_{i}$ matched in industry ${ }_{j}$;

$\triangle R E V_{i t j}=$ The change of revenues for estimation portfolio firm ${ }_{i}$ in industry ${ }_{j}$ from year ${ }_{t-1}$ to year $t$;

$\triangle R E C_{i t j}=$ The change in receivables for estimation portfolio firm $i$ industry ${ }_{j}$ from year ${ }_{t-1}$ to year

$P P E_{i t j}=$ Gross property, plant and equipment for estimation portfolio firm ${ }_{i}$ in industry ${ }_{j}$ for the year $t$;

$R O A_{i t j}=$ Return on assets is net income before extraordinary items for deflated by the beginning total asset of previous year $\left(A_{i t j-1}\right)$ for firm ${ }_{i}$ matched in industry ${ }_{j}$;

$B_{0}=$ Unstandardized regression coefficient, i.e. it shows the measures of $D A\left(T A A_{i t j} / A_{i t j-1}\right)$ when all independents variables are 0 .

$\beta_{1}=$ Unstandardized regression coefficient for $\left(\Delta R E V_{i t j}-\Delta R E C_{i t j} / A_{i t j-1}\right)$.

$\beta_{2}=$ Unstandardized regression coefficient for $\left(P P E_{i t j} / A_{i t j-1}\right)$.

$\beta_{3}=$ Unstandardized regression coefficient for $\left(R O A_{i t}-1\right)$.

Then, in order to test the hypotheses of a significant difference between the crisis period and before, paired sample T-test was used as it enables the comparison of the same variable in two different but related samples (Norusis, 2008; Ousama et al. 2011; Mohamed et al. 
2012). There are two years in each of the two periods in this study, namely the period during the financial crisis $(2008 ; 2009)$ and the period before the financial crisis $(2005 ; 2006)$.

In this study, the absolute value of DA is used to measure the magnitude of EM. Specifically, ADA is the average of the absolute values of both positive and negative DA. Since only absolute values are computed, regardless of whether the DA are positive or negative, therefore, the direction of EM cannot be analysed when using ADA. In fact, hypothetically, if the Malaysian companies were using income increasing EM practices in Year 1, positive DA would have higher values, and negative DA would have lower values. Hence the absolute values of both positive and negative DA would be calculated and averaged. Then, in Year 2, if the companies decided to use income decreasing EM practices, negative DA would increase, and positive DA would decrease. However, when the ADA for the positive and negative DA is averaged, ADA for both Year 1 and 2 could be approximately the same. Due to these reasons, it is important to distinguish between positive DA and negative DA in order to analyse EM practices during the financial crisis period more accurately.

Finally, simple multivariate regressions are run as additional tests. The regression model is as follows:

$$
\mathrm{DA}=\alpha+\beta_{1} \text { Crisis }+\beta_{2} \text { IFRS }+\beta_{3} \text { Size }+\varepsilon
$$

Where:

$D A=$ discretionary accruals calculated based on the modified Jones model by Kothari et al. (2005) to avoid misspecification

Crisis $=$ a dichotomous variable, which takes a value of 1 for crisis period and 0 otherwise

IFRS $=$ a dichotomous variable, which takes a value of 1 after IFRS adoption and 0 before

Size = company size measured by total assets

$\varepsilon=$ residual

The dependent variable in the regression above, DA, is substituted with positive DA and negative DA in later regressions. The last regression takes into consideration the effect of both the financial crisis period and the introduction of IFRS on DA.

$$
\mathrm{DA}=\gamma+\delta_{1} \text { CriIFRS }+\delta_{2} \text { Size }+\varepsilon
$$

CriIFRS is the integration variable between crisis period and IFRS. Other variables are as in regression 1 above. Again, DA is replaced by positive DA and negative DA in later regressions.

\section{RESULTS AND DISCUSSION}

Table 1 provides a list of the number of companies that form the sample of this study based on their industrial sector. This sample represents $34 \%$ of the population of the listed companies on Bursa Malaysia in 2009 after removing the financial sector. 
Table 1: Number of Companies according to their Industrial Sectors

\begin{tabular}{|c|c|}
\hline Name of Sectors & $\begin{array}{c}\text { No. of } \\
\text { companies }\end{array}$ \\
\hline Construction & 15 \\
\hline Consumer Products & 41 \\
\hline Industrial Products & 80 \\
\hline Plantation & 14 \\
\hline Properties & 26 \\
\hline Trading and Services & 51 \\
\hline Total & $\mathbf{2 3 4}$ \\
\hline
\end{tabular}

The findings of this study are discussed in the order of the hypotheses. Therefore, Table 2 presents a comparison of the magnitude of EM during and before the crisis using both models (Modified Jones models by Dechow et al. (1995) and Kothari et al. (2005), respectively).

Table 2: Absolute Discretionary Accruals (ADA) Before and During Crisis

\begin{tabular}{|c|c|c|c|c|c|c|}
\hline \multirow{2}{*}{ ADA } & \multicolumn{3}{|c|}{ M1 } & \multicolumn{3}{|c|}{ M2 } \\
\hline & $\mathbf{N}$ & Mean & Sig. T & $\mathbf{N}$ & Mean & Sig.T \\
\hline Before crisis & $\begin{array}{c}46 \\
8\end{array}$ & 0.2593 & \multirow{2}{*}{$0.000 * * *$} & 468 & 0.2255 & \multirow{2}{*}{$0.000 * * *$} \\
\hline During crisis & $\begin{array}{c}46 \\
8\end{array}$ & 0.1659 & & 468 & 0.1638 & \\
\hline
\end{tabular}

Regardless of the model used (M1 or M2), the ADA before the crisis was found to be significantly higher $(\mathrm{p}<0.01)$ than the crisis period. Hence $\mathrm{H} 1$, which states that there is a significant difference between EM practices (in terms of magnitude) before and during the financial crisis, is supported. Furthermore, higher ADA before compared to during the crisis seems to indicate that Malaysian companies were more conservative in terms of practising EM during the crisis compared to the period before the crisis. However, this finding is inconsistent with findings of previous literature (Johl et al., 2007; Iatridis and Dimitras, 2013; Mollik et al., 2013) that found EM practices to be more rampant during the financial crisis. Therefore, further analyses were carried out using DA in order to better comprehend the issue, as well as compare with DA from prior studies.

Although not presented in Table 2, the average DA for the period before the financial crisis was 0.073 (M1) and 0.051 (M2), while the average during the crisis was -0.017 (M1) and 0.001 (M2), respectively. These results indicate that, on average, there was generally more income increasing EM before the crisis than during the crisis. It is interesting to

\footnotetext{
${ }^{6}$ The figures are only for 2009, however as explained in subsection 3.2, data was collected for the period 2004 to 2009 resulting in the final sample of 1,189 firm years.
} 
compare these findings with Iatridis and Dimitras (2013) results in Europe as the DA in their sample of 5 European countries ranged between -0.10 for Ireland and -0.46 for Greece. Hence, the DA of this study seems less negative than those of Iatridis and Dimitras' (2013) DA. However, Filip and Raffournier (2014) also calculated DA based on the modified Jones model $^{7}$. Their DA for the pre-crisis and crisis periods were 0.176 and 0.115 , respectively. This indicates that in comparison to the 16 European countries, which were the sample for Filip and Raffournier's (2014) study, the EM in the Malaysian companies of this study had less positive EM during the pre-crisis period, but more negative or less positive EM during the crisis period. The DA figures of this study could only be compared to the findings of the European studies as the literature on Asian financial crisis and the Asian study on the global financial crisis (Rusmin et al., 2012) either used a different measure of EM or did not present the results in a comparable way.

Next, Table 3 presents the results of positive and negative DA. The results show that positive DA was significantly less positive $(p<0.01)$ in both models during the crisis period compared to the pre-crisis period. At the same time, negative DA was significantly more negative $(\mathrm{p}<0.01)$ during the crisis period than compared to the pre-crisis period. These results support $\mathrm{H} 2$ and seem to be consistent with big bath theory as Malaysian companies seem to be using income decreasing EM during the crisis compared to before.

Table 3: Positive and Negative Discretionary Accruals (DA)

\begin{tabular}{|c|c|c|c|c|c|c|}
\hline \multirow{2}{*}{ Panel A: Positive DA } & \multicolumn{3}{|c|}{ M1 } & \multicolumn{3}{|c|}{ M2 } \\
\hline & $\mathbf{N}$ & Mean & Sig.T & $\mathbf{N}$ & Mean & $\begin{array}{l}\text { Sig.T } \\
\end{array}$ \\
\hline Before crisis & 273 & 0.2913 & \multirow{2}{*}{$0.000 * * *$} & 240 & 0.2295 & \multirow{2}{*}{$0.000 * * *$} \\
\hline During crisis & 211 & 0.1208 & & 239 & 0.1648 & \\
\hline \multicolumn{4}{|l|}{ Panel B: Negative DA } & & & \\
\hline Before crisis & 195 & -0.0807 & \multirow{2}{*}{$0.000 * * *$} & 228 & -0.0790 & \multirow{2}{*}{$0.000 * * *$} \\
\hline During crisis & 257 & -0.1645 & & 229 & -0.1597 & \\
\hline
\end{tabular}

The results in Table 3 above were compared to the results of Filip and Raffournier (2014), who also presented positive DA and negative DA for their sample of 16 European countries. Their positive DA were 0.216 and 0.112 for the pre-crisis and crisis period, respectively. Therefore, based on positive DA, income increasing EM of Malaysian companies in the pre-crisis period seem slightly more aggressive (23\% compared to $22 \%$ ), but may be deemed comparable to those in Europe. Similarly, positive DA of this study's sample decreased during the crisis period but remained higher than positive DA of Filip and Raffournier (2014), respectively (16\% compared to $11 \%$ ).

On the other hand, negative DA for Filip and Raffournier's (2014) study was $-0.110^{8}$ during the pre-crisis period and -0.085 during the crisis period. Therefore, during the precrisis period, it would seem that the negative DA for this sample's study was less negative

\footnotetext{
${ }^{7}$ Although Filip and Raffournier (2014) had other computations of DA, they were not comparable, hence only the DA from the modified Jones model by Kothari et al. (2005) was compared with.

${ }^{8}$ Filip and Raffournier (2014) did not include the 'minus' signs indicating negative for 'negative DA' as it has already been labelled.
} 
compared to Filip and Raffournier's (2014) results (8\% compared to $11 \%$ ). However, during the crisis period, the negative DA for the Malaysian companies in this study became more negative compared to the pre-crisis period, whereas the European companies in Filip and Raffournier's (2014) study became less negative. Therefore, it would seem that the Malaysian companies were involved in more aggressive income decreasing EM practices during the crisis period, whereas their European counterparts were reducing EM practices (both positive and negative DA had smaller values). Hence, the findings shown in Table 3 support $\mathrm{H} 2$ and is line with big bath theory.

Further analysis was carried out on the frequency of positive and negative DA, based on ' $\mathrm{N}$ ' presented in Table 3. Out of the 468 companies in the sample, there were $273(58 \%)$ and $240(51 \%)$ companies practising income increasing EM before the crisis compared to those practising income decreasing EM, i.e. 195 (42\%) and 228 (49\%), respectively. However, during the crisis period, the frequency of companies with positive DA declined to 211 (45\%) based on the Modified Jones model by Dechow et al. (1995) [M1] but remained the same at $239(51 \%)$ based on Modified Jones Model by Kothari et al. (2005) [M2]. Consequently, the frequency of negative DA increased to $257(55 \%)$ based on M1, but remained constant at $229(49 \%)$ for M2. These results indicate that, according to M1, more Malaysian companies were employing income increasing EM practices before the crisis period, but more companies employed income decreasing EM during the crisis period. However, the frequency of practising income increasing and decreasing EM practices did not change before and during the crisis based on M2.

Then, to better understand EM practices during the crisis compared to before, mean DA, mean ADA, positive and negative DA were further analysed according to years (2005, 2006, 2008 and 2009) using both models. The results are presented in Figures 1 - 4 below.

\section{Figure 1: Mean Discretionary accruals and Mean Absolute discretionary accruals using Modified Jones model by Dechow et al. (1995)}

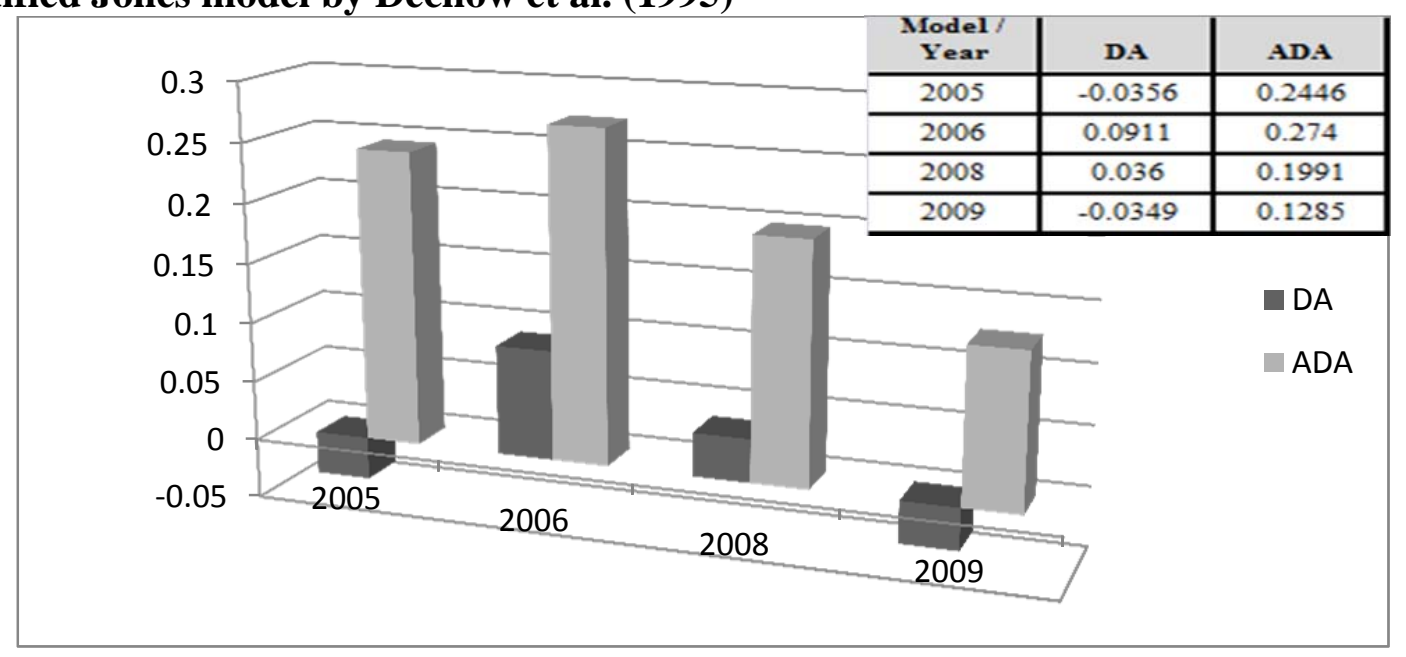

Figure 1 presents the mean discretionary accruals and mean absolute discretionary accruals calculated based on the modified Jones model by Dechow et al. (1995) for the precrisis period 2005 and 2006 as well as the crisis period 2008 and 2009. Figure 1 shows that, on average, DA was negative in 2005 but became positive in 2006 after IFRS were introduced. DA decreased, albeit still positive, when the financial crisis started in 2008. DA decreased further in 2009 into negative DA. A similar pattern emerged with ADA where EM was at its highest magnitude in 2006. ADA decreased during the crisis period in 2008 and 
decreased further in 2009. The finding of increased EM with IFRS adoption is consistent with prior studies (Ahmed et al., 2013; Li et al. 2014).

Figure 2 illustrates positive DA and negative DA calculated based on the modified Jones model by Dechow et al. (1995). DA became more positive and less negative in 2006 after IFRS was introduced. Then, on average, DA were the least positive and least negative during the financial crisis period in 2008. However, positive DA increased slightly in 2009, and negative DA became more negative.

Figure 2: Mean Positive and Negative Discretionary Accruals using Modified Jones model by Dechow et al. (1995)

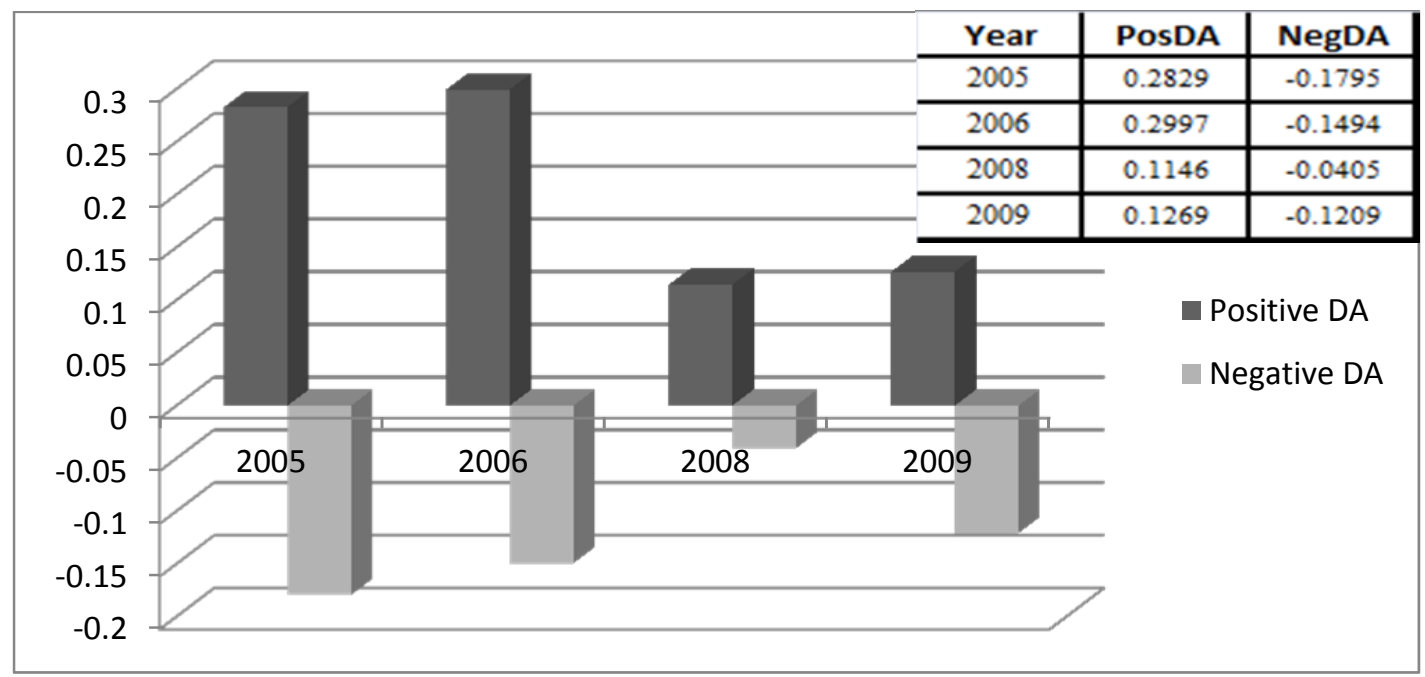

The DA and ADA in Figure 3 were calculated using the Modified Jones model by Kothari et al. (2005). Figure 3 shows a similar pattern to Figure 1 above, where DA and ADA were highest in 2006. On average, DA fell substantially but remained positive during the financial crisis in 2008, but became negative in 2009. ADA were also lowest in 2008 but recovered in 2009.

Figure 3: Mean Discretionary accruals and Mean Absolute discretionary accruals using Modified Jones model by Kothari et al. (2005)

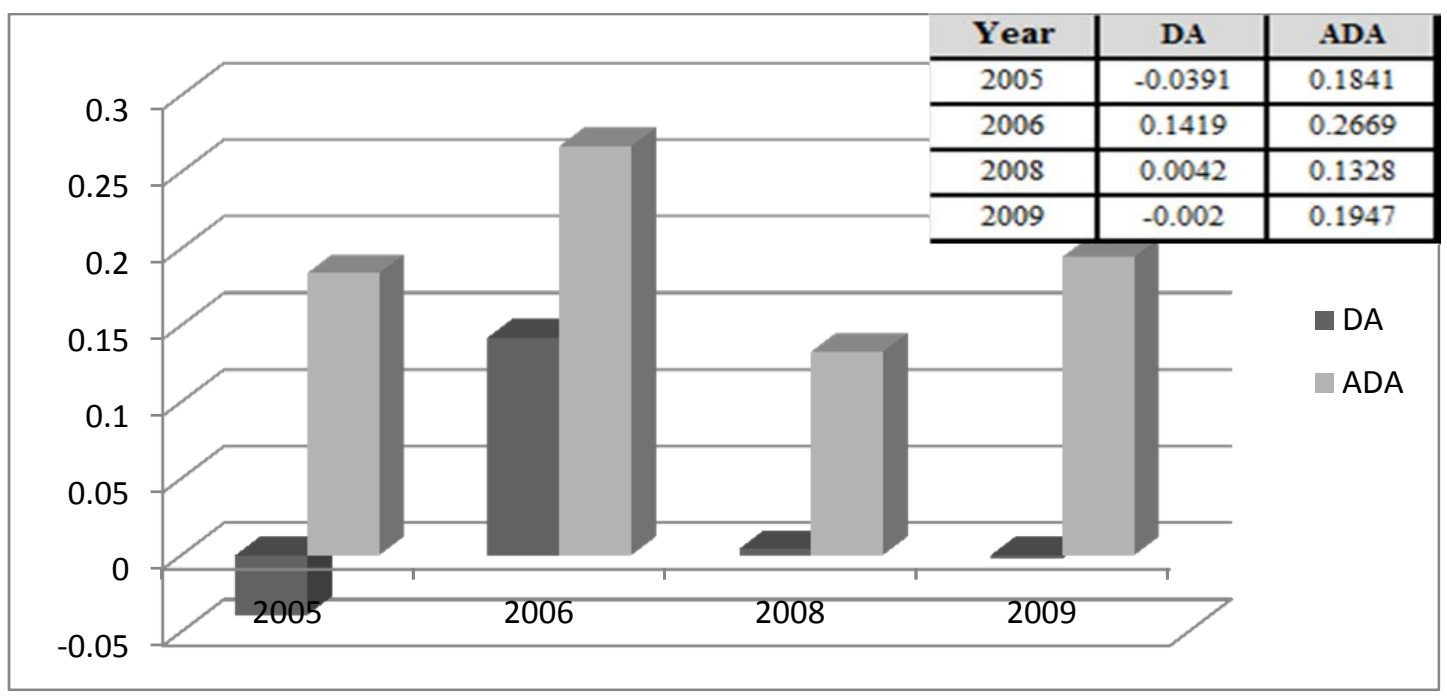


Figure 4 reveals some dissimilar patterns to Figure 2. The latter figure uses the Modified Jones model by Kothari et al. (2005). Based on the modified Jones model by Kothari et al. (2005), on average, positive DA were highest in 2005, but negative DA were least negative in 2006, subsequent to IFRS adoption. Similar to Figure 2, positive DA in Figure 4 were least positive in 2008. However, unlike Figure 2, negative DA were most negative in 2008 (Figure 4), when the financial crisis hit. Nevertheless, positive DA increased in positivity, and negative DA became less negative in 2009.

Figure 4: Mean positive and negative discretionary accruals using Modified Jones model by Kothari et al. (2005)

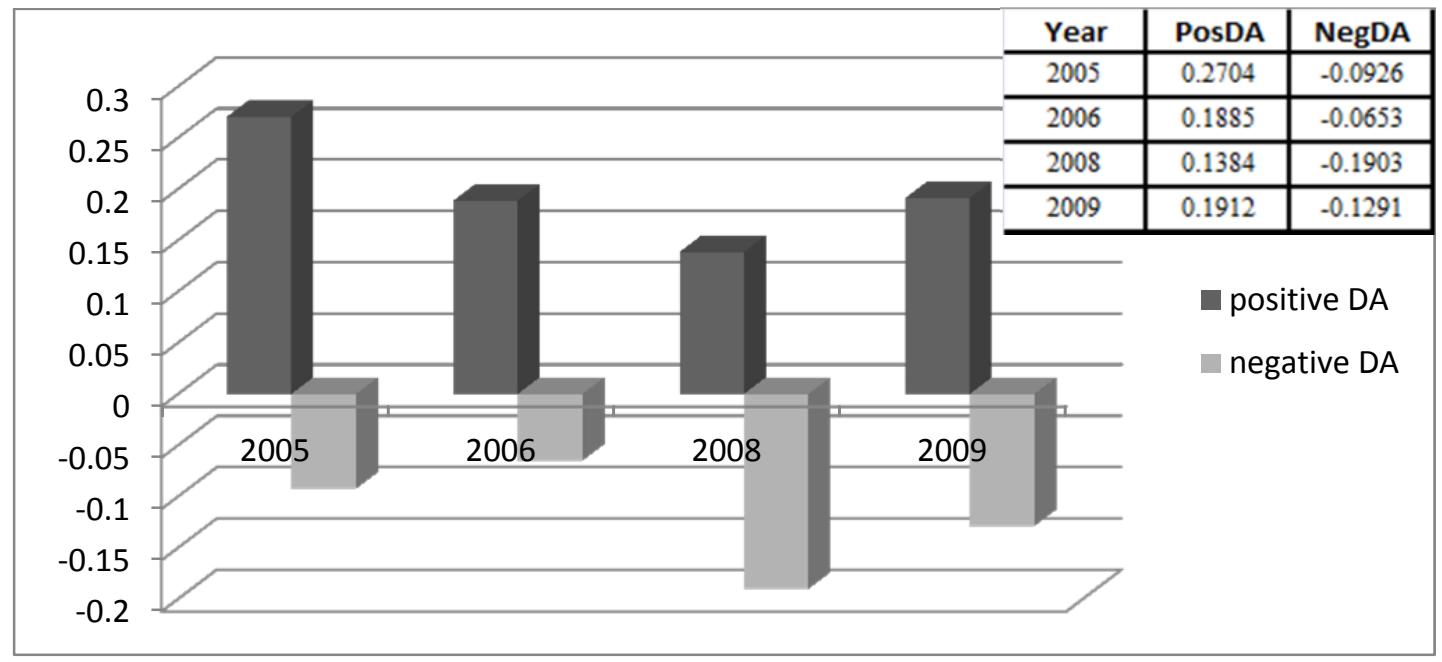

Therefore, the figures above are a preliminary indication of results that generally support $\mathrm{H} 2$ that EM is more negative or less positive during the financial crisis period, as shown in the results of Table 3 .

Then, as additional tests, the study regressed crisis period and IFRS as independent variables against DA, positive DA and negative DA as dependent variables. Size of the company was a control variable in the regressions. Prior to running the regressions, tests for normality and multicollinearity were conducted. Total assets, the proxy for size, was not normal. Hence Van der Waerden's normalised scores ${ }^{9}$ had to be used. However, there was no problem with multicollinearity.

Table 4: Results of Regression 1

\begin{tabular}{|l|c|c|c|}
\hline Dependent Variable & DA & Positive DA & Negative DA \\
\hline Constant & $-0.035^{* *}$ & $0.122^{* * *}$ & $-0.323^{* * *}$ \\
\hline Crisis & $-0.247^{* * *}$ & $-0.259^{* * *}$ & 0.07 \\
\hline IFRS & $0.252^{* * *}$ & $0.207^{* * *}$ & $0.015^{* *}$ \\
\hline Size & $0.064^{* *}$ & $0.187^{* * *}$ & -0.075 \\
\hline Adjusted R & 0.053 & 0.085 & 0.040 \\
\hline
\end{tabular}

\footnotetext{
${ }^{9}$ The Van der Waerden's normalised scores is an approach to normalize the non-normality of the data by dividing the actual data distribution into a number of observations plus one region, on the basis that each region has equal probability. This approach has been suggested by Cooke (1998).
} 
The findings in Table 4 indicate that EM is significantly negative during the crisis period based on DA. It is also significantly less positive based on positive DA. However, it is not significantly more negative based on negative DA. On the other hand, EM seems to be significantly more positive after IFRS based on all three EM measures. Hence, these findings seem to be consistent with the results of prior studies (Ahmed et al., 2013; Li et al., 2014) in terms of the IFRS adoption potentially reducing EM practices. In addition, this finding is in line with institutional theory, as the presence of regulation influences practices of companies (mandatory isomorphism).

Company size weakly and strongly positively affects DA and positive DA, respectively. This means that bigger companies tend to have more positive DA, but it is not significant for negative DA. It is quite reasonable to expect low adjusted $\mathrm{R}^{2}$ for the three regression models as there would be many other variables that would affect EM. Nevertheless, the F-value is significant for all regression models, indicating a good fit. More importantly, even after controlling for size, EM is significantly negative during the financial crisis period, hence consistent with $\mathrm{H} 2$. This finding provides additional support to the t-tests above on the occurrence of big-bath.

Table 5: Results of Regression 2

\begin{tabular}{|l|c|c|c|}
\hline Variables & DA & Positive DA & Negative DA \\
\hline Constant & $0.028^{* * *}$ & $0.168^{* * *}$ & $-0.168^{* * *}$ \\
\hline CriIFRS & $-0.102^{* * *}$ & $-0.159^{* * *}$ & $0.135^{* * *}$ \\
\hline Size & $0.067^{* *}$ & $0.189^{* * *}$ & $-0.083^{*}$ \\
\hline Adjusted $\mathrm{R}^{2}$ & 0.012 & 0.054 & 0.019 \\
\hline
\end{tabular}

In Table 5, the integrated variable CrilFRS reflects the crisis period taking into consideration the introduction of IFRS. The coefficient of the variable CriIFRS is less negative than the Crisis variable in Table 4 for both DA and positive DA. This indicates that, for both DA and positive DA, EM is less negative during the crisis period when taking into consideration the IFRS. However, in the context of negative DA, the integration variable is significantly positive with negative DA, whereas it was not significant for Crisis variable in Table 4. This result suggests that during the crisis period, when taking into consideration, the IFRS, negative DA was less negative, hence resulting in a significantly positive coefficient for the CriIFRS variable. In other words, the adoption of IFRS in Malaysia plays a role in reducing income decreasing EM practices during the global financial crisis. Therefore, based on Table 5, all EM variables indicate that IFRS influences EM during the financial crisis period. These findings support H3.

\section{CONCLUSION}

This study investigates earnings management behavior during the 2008 financial crisis in Malaysia and compares it with EM during the pre-crisis period. In addition, this study also takes into consideration the fact that Malaysian companies adopted IFRS just two years prior to the global financial crisis and that could also have some influence on EM during the crisis period. This study used two models, namely the modified Jones model by Dechow et al. (1995) and the modified Jones model by Kothari et al. (2005) to calculate discretionary accruals, which are the proxies for earnings management.

The findings of this study support the big bath theory by providing evidence that there are more negative and less positive EM practices during the financial crisis period. This is in contrast to prior literature in Europe (Filip and Raffournier, 2014) that had less EM practices during the global financial crisis. Therefore, the findings from Malaysian companies' data 
reveal that managers in developing countries like Malaysia, do indeed take advantage of the crisis period to manipulate earnings downwards. Hence, this study may be of interest to researchers in other developing Asian countries, as their managers may also behave similarly in a crisis situation. Nevertheless, the findings of this study are congruent with the benefits of accounting regulation as the findings suggest that IFRS adoption is capable of reducing EM practices during a financial crisis. The influence of IFRS would be in line with coercive isomorphism under the institutional theory. The findings of the study on IFRS adoption during the crisis period, although preliminary and inconclusive, may be of use to accounting regulators and researchers to venture into further research.

The limitation of this study is that it uses rudimentary measures to proxy crisis period and IFRS in the regressions. Therefore, future research could consider more refined measures to study the effect of accounting regulation on EM during abnormal periods. In addition, this study only included size of the company as a control variable. Future research is suggested to include more control variables to improve the regression equation. Nevertheless, it is hoped that the findings of this study would inspire more research on EM during abnormal periods, such as financial crisis period, whilst taking accounting regulation into consideration, particularly in Asian countries.

\section{REFERENCES:}

Abbadi, S. S., Hijazi, Q. F., \& Al-Rahahleh, A. S. (2016). Corporate Governance Quality and Earnings Management: Evidence from Jordan. Australasian Accounting, Business and Finance Journal, Vol. 10, No. 2, pp. 54-75. https://doi.org/10.14453/aabfj.v10i2.4

Abdullah, S. N., Mohd-Yusof, N. Z., \& Mohd-Nor, M. (2010). Financial Restatements and Corporate Governance among Malaysian Listed Companies. Managerial Auditing Journal, Vol. 25, No. 6, pp. 526-552. https://doi.org/10.1108/02686901011054854

Abdullah, S. N., \& Mohd-Nasir, N. (2004). Accruals Management and the Independence of the Boards of Directors and Audit Committees. IIUM Journal of Economics and Management, Vol. 12, No.1, pp. 1-31.

Abdul-Rahman, R. \& Mohd-Ali, F. H. (2006). Board, Audit Committee, Culture and Earnings Management: Malaysian Evidence. Managerial Auditing Journal, Vol. 21, No.7, pp.783-804. https://doi.org/10.1108/02686900610680549

Ahmed, A. S., Neel, M., \& Wang, D. (2013). Does mandatory adoption of IFRS improve accounting quality? Preliminary evidence. Contemporary Accounting Research, Vol. 30, No. 4, pp. 1344-1372. https://doi.org/10.1111/j.1911-3846.2012.01193.x

Al-Absy, M. S. M. Ismail, K. N. K., Chandren, S. (2018). Accounting expertise in the audit committee and earnings management. Accounting expertise in the audit committee and earnings management. Vol. 14, No. 3, pp.451-476. https://doi.org/10.15208/beh.2018.33

Aljifri, K. (2007). Measurement and Motivations for Earnings Management: A Critical Perspective. Journal of Accounting - Business \& Management, Vol. 14, pp. 75-95.

Al-Jaifi, H. A. (2016). Ownership concentration, earnings management and stock market liquidity: evidence from Malaysia. The International Journal of Business in Society, Vol. 17, No. 3, pp. 490-510. https://doi.org/10.1108/CG-06-2016-0139

Alves, S. (2012). Ownership Structure and Earnings Management: Evidence from Portugal. Australasian Accounting, Business and Finance Journal, Vol. 6, No. 1, pp. 57-73. 
Al-Ghazzawi, A. M., \& Alsoboa, S. S. (2016). Impact of Improvements to the International Accounting Standards on Earnings Management in the Jordanian Industrial Corporations. Journal of Accounting and Finance, Vol. 16, No. 2, pp. 58-71.

Al-Thuneibat, A. A., Al-Issa, R. T. I., \& Baker, R. A. A. (2011). Do Audit Tenure and Firm Size Contribute to Audit Quality? Managerial Auditing Journal, Vol. 26, No. 4, pp. 317-334. https://doi.org/10.1108/02686901111124648

Angabini, A., \& Wasiuzzaman, S. (2011). GARCH Model and the Financial Crisis: A Study of Malaysian Stock Market. The International Journal of Applied Economics and Finance, pp. 1-11.

Bartov, E., Gul, F., \& Tsui, J. (2001). Discretionary-accruals Models and Audit Qualifications. Journal of Accounting and Economics, Vol. 30, pp. 421-452 https://doi.org/10.1016/S0165-4101(01)00015-5

Basheer, S. (2003). Daliloka yla Alparnamag Aleehsahi SPSS 10.0. Alma'ahad Alarabi laltadrib wa Albohwth Aleehsaiah, Baqhdad.

Bauwhede, H., Willekens, M., \& Gaeremynck, A. (2003). Audit Firm Size, Public Ownership and Firm's Discretionary Accruals Management. The International Journal of Accounting, Vol. 38, pp. 1-22. https://doi.org/10.1016/S0020-7063(03)00004-9

Black, K. (2004). Business statistics: For contemporary decision making (4 ${ }^{\text {th }}$ edn.). U.S.A: Leyh Publishing, LLC.

Butler, M., Leone, A., \& Willenborg, M. (2004). An Empirical Analysis of Auditor Reporting and its Association with Abnormal Accruals. Journal of Accounting and Economics, Vol. 37, pp. 139-165. https://doi.org/10.1016/j.jacceco.2003.06.004

Charitou, A., Lambertides, N., \& Trigeorgis, L. (2007). Managerial discretion in distressed firms. The British Accounting Review, Vol. 39, pp. 323-346. https://doi.org/10.1016/j.bar.2007.08.003

Charoenwong, C., \& Jiraporn., P. (2009). Earnings Management to Exceed Thresholds: Evidence from Singapore and Thailand. Journal of Multinational Financial Management, Vol. 19, pp. 221-236. https://doi.org/10.1016/j.mulfin.2008.12.001

Chen, K., Lin, K., \& Zhou, J. (2005). Audit quality and earnings management for Taiwan IPO firms. Managerial Auditing Journal, Vol. 20, No. 1, pp. 86-104.

https://doi.org/10.1108/02686900510570722

Chia Y. M., Lapsley I., \& Lee H. (2007). Choice of auditors and earnings management during the Asian financial crisis. Managerial Auditing Journal, Vol. 22 No. 2, pp. 177-196. https://doi.org/10.1108/02686900710718672

Chi, J., \& Gupta M. (2009). Overvaluation and Earnings Management. Journal of Banking \& Finance, Vol. 33, pp. 1652-1663. https://doi.org/10.1016/j.jbankfin.2009.03.014

Cimini, R. (2015). How has the financial crisis affected Earnings Management? A European Study. Applied Economics, Vol. 47, No. 3, pp. 302-317.

https://doi.org/10.1080/00036846.2014.969828

Cooke, T. E. (1998). Regression Analysis in Accounting Disclosure Studies. Accounting and Business Research, Vol. 28, No. 3, pp. 209-224. https://doi.org/10.1080/00014788.1998.9728910 
Cooper, D., \& Schindler, P. (2003). Business research methods. Eighth edition. USA: Mc GRAW - HILL.

Cooper, D., \& Schindler, P. (2008). Business research methods. Tenth edition. USA: Mc GRAW - HILL.

Crotty, J. (2009). Structural causes of the global financial crisis: a critical assessment of the 'new financial architecture'. Cambridge Journal of Economics, Vol. 33, pp. 563-580. https://doi.org/10.1093/cje/bep023

Da Silva, A. F., Weffort, E. F. J., Flores, E. D. S., \& Da Silva, G. P. (2014). Earnings Management and Economic Crisis in the Brazilian Capital Markets. Revista de Administração de Empresas, Vol. 54, No. 3, pp. 268-283.

https://doi.org/10.1590/S0034-759020140303

Davis, D., \& Cosenze, R. (1993). Business Research for Decision Making (3 ${ }^{\text {rd }}$ edn). Wadsworth publishing company.

DeAngelo, L. (1986). Accounting Numbers as Market Valuation Substitutes: A Study of Management Buyouts of Public Stockholders. The Accounting Review, Vol. 61, No. 3. pp. 400-420.

Dechow, P. M., Sloan, R., \& Sweeney, A. (1995). Detecting Earnings Management. The Accounting Review, Vol. 70, No. 2, pp. 193-225.

Dechow, P., \& Skinner, D. (2000). Earnings Management: Reconciling the Views of Accounting Academics, Practitioners and Regulators. SSRN Working paper. Available from: $\quad$ http://papers.ssrn.com/sol3/papers.cfm? abstract $i d=218959$ https://doi.org/10.2139/ssrn.218959

Emory, C. W. (1985). Business Research Methods (3 ${ }^{\text {rd }}$ edn). Homewood, IL, Irwan.

Filip, A., \& Raffournier, B. (2014). Financial Crisis and Earnings Management: The European Evidence. The International Journal of Accounting, Vol. 49, pp. 455-478. https://doi.org/10.1016/j.intacc.2014.10.004

Goel, S. (2016). The Earnings Management Motivation: Accrual Accounting vs. Cash Accounting. Australasian Accounting, Business and Finance Journal, Vol. 10, No. 3 , pp. 48-66. https://doi.org/10.14453/aabfj.v10i3.4

Goh, S.K., \& Lim, M.M. (2010). The Impact of the Global Financial Crisis: The Case of Malaysia, Third World Network, Malaysia.

Habib, A., Bhuiyan, M.B., \& Islam, A. (2013). Financial distress, earnings management and market pricing of accruals during the global financial crisis. Managerial Finance, Vol. 39, No, 2, pp. 155-180. https://doi.org/10.1108/03074351311294007

Hafiza Aishah Hashim, \& Devi, S. (2008). Board Independence, CEO Duality and AccrualsManagement: Malaysian Evidence. Asian Journal of Business and Accounting, Vol. 1, No.3, pp. 27-46. https://doi.org/10.1111/j.1475679X.2008.00269.X

Hashanah I., Mohd-Iskandar, T., \& Rahmat, M. M. (2008). Corporate Reporting Quality, Audit Committee and Quality of Audit. Malaysian Accounting Review, Vol. 7, No. 1. 
Healy, P. (1985). The Effect of Bonus Schemes on Accounting Decisions. Journal of Accounting and Economics, Vol. 7, pp.85-107. https://doi.org/10.1016/0165-4101(85)90029-1

Healy, P., \& Wahlen, J. (1999). A Review of the Earnings Management Literature and Its Implications for Standard Setting. American Accounting Association, Accounting Horizons, Vol. 13, No. 4, pp. 365-383. https://doi.org/10.2308/acch.1999.13.4.365

Iatridis, G., \& Dimitras, A. (2013). Financial Crisis and Accounting Quality: Evidence from Five European Countries. Advances in Accounting, Incorporating Advances in International Accounting, Vol. 29, pp. 154-160. https://doi.org/10.1016/j.adiac.2013.03.001

IMF International Mandatory Fond report (2008). Retrieved March 4, 2010, available at: http://www.imf.org/external/pubs/ft/ar/2008/eng/pdf/ar08 eng.pdf

IMF International Mandatory Fond report (2009). Retrieved March 4, 2010, available at: http://www.imf.org/external/pubs/ft/ar/2009/eng/pdf/ar09_eng.pdf

IMF International Mandatory Fond report (2009). The Global Financial Crisis: Explaining Cross-Country Differences in the Output Impact: Working Paper, Retrieved May 24, 2013, available at:

http://www.igidr.ac.in/money/mfc-13/mfc-12/Pelin\%20Berkmen_The\%20Global \%20Financial\%20Crisis.pdf

IMF International Mandatory Fond report (2010). Retrieved May 9, 2012, available at:

http://www.imf.org/external/pubs/ft/scr/2010/cr10265.pdf

Jenkins, D., Kane, G., \& Velury, U. (2006). Earnings Quality Decline and the Effect of Industry Specialist Auditors: An analysis of the Late 1990s. Journal of Accounting and Public Policy, Vol. 25, pp. 71-90. https://doi.org/10.1016/j.jaccpubpol.2005.11.003

Johl, S., Jubb, C., \& Houghton, K. (2007). Earnings Management and the Audit Opinion: Evidence from Malaysia. Managerial Auditing Journal, Vol. 22, No. 7, pp. 688-715. https://doi.org/10.1108/02686900710772591

Jordan, C.E., \& Clark, S.J. (2015). Do New CEOs Practice Big Bath Earnings Management Via Goodwill Impairments? Journal of Accounting and Finance, Vol. 15, No. 2, pp. 11-21.

Klein, A. (2002). Audit Committee, Board of Director Characteristics and Earnings Management. Journal of Accounting and Economics, Vol. 33, pp. 275-400. https://doi.org/10.1016/S0165-4101(02)00059-9

Kothari, S. P., Leone, A. J., \& Wasley, C. (2005). Performance Matched Discretionary Accruals Measures. Journal of Accounting and Economics, Vol. 39, pp. 163-197. https://doi.org/10.1016/j.jacceco.2004.11.002

KPMG (2009). Audit Committee Roundtable Highlights. Retrieved May 26, 2013, available at:

http://www.kpmg.com/MY/en/IssuesAndInsights/ArticlesPublications/Pages/AuditCo mmitteeRoundtableHighlights2009.aspx 
Li, Z., Liu, Q., \& Luo, L. (2014). International Financial Reporting Standards (IFRS) and Earnings Management: Evidence from China. The Chinese Accounting Professors' Association of North America (CAPANA), available at: http://www.capana.net/www/conference2014/LiLiuLuo.pdf

Liu, Q., \& Lu, Z. J. (2007). Corporate Governance and Earnings Management in the Chinese Listed Companies: A Tunneling perspective. Journal of Corporate Finance, 13, 881906. https://doi.org/10.1016/j.jcorpfin.2007.07.003

Masruki R. \& Azizan NA. (2012). The Impact of Asian Financial Crisis to Earnings Management and Operating Performance in Malaysia. The Social Sciences, Vol. 7, No. 4, pp. 510-516. https://doi.org/10.3923/sscience.2012.510.516

MICPA (2007). History of Accounting and Auditing in Malaysia, The Malaysian Institute of Certified Public Accountants, retrieved 24 August 2017, available at http://www.micpa.com.my/micpanew/member/handbook-history.asp

Mohamad, M. H., Hafiz-Majdi, A. \& Shawtari, F. A. (2012). Corporate Governance and Earnings Management in Malaysian Government Linked Companies. The Impact of GLCs' Transformation Policy. Asian Review of Accounting Journal, Vol. 20, No. 3, pp. 241-258. https://doi.org/10.1108/13217341211263283

Mohd-Saleh, N., \& Ahmed, K. (2006). Earnings Management of Distressed Firms During Debt Renegotiation. Accounting and Business Research, Vol. 35, No. 1, pp. 69-86. https://doi.org/10.1080/00014788.2005.9729663

Mohd-Saleh, N., Mohd-Iskandar, T., \& Rahmat, M. M. (2005a). Avoidance of Reported Earnings Decreases and Losses: Evidence from Malaysia. Malaysian Accounting Review, Vol. 4, No.1.

Mohd-Saleh, N., Mohd-Iskandar, T., \& Rahmat, M. M. (2005b). Earnings Management and Board Characteristics: Evidence from Malaysia. Malaysian Accounting Review, Vol. 24, No.1, pp. 77-103.

Mohd-Saleh, N., Mohd-Iskandar, T., \& Rahmat, M. M. (2007). Audit Committee Characteristics and Earnings Management: Evidence from Malaysia. Asian Review of Accounting, Vol.15, No. 2, pp. 147-163. https://doi.org/10.1108/13217340710823369

Nahar N., \& Ismail, K. N. K., (2016). Women directors, family ownership and earnings management in Malaysia. Asian Review of Accounting. Vol. 24 No. 4, pp. 525-550. https://doi.org/10.1108/ARA-07-2015-0067

Naidu, D., \& Patel, A. (2013). A Comparison of Qualitative and Quantitative Methods of Detecting Earnings Management: Evidence from two Fijian Private and two Fijian State-owned Entities. Australasian Accounting, Business and Finance Journal, Vol. 7, No. 1, pp. 79-98. https://doi.org/10.14453/aabfj.v7i1.6

Nasir, N. A., Ali, M. J., Razzaque, R. \& Ahmed, K. (2018). Real earnings management and financial statement fraud: evidence from Malaysia. International Journal of Accounting \& Information Management, Vol. 26 No. 4, pp. 508-526. https://doi.org/10.1108/IJAIM-03-2017-0039 
Nieken, P., \& Sliwka, D. (2015). Management Changes, Reputation, and "Big Bath"Earnings Management. Journal of Economics and Management Strategies, Vol. 24, No. 3, pp. 501-522. https://doi.org/10.1111/jems.12101

Norusis, M. J. (2008). SPSS 16. 0 Guide to Data Analysis. Prentice Hall Higher Education.

Osborne, Jason, \& Waters, E. (2002). Four assumptions of multiple regression that researchers should always test. Practical Assessment, Research \& Evaluation, 8(2). Retrieved May 11, 2011 available at: http://PAREonline.net/getvn.asp?v=8\&n=2

Ousama, A. A., Fatima, A. H. \& Hafiz-Majdi, A. (2011). An Exploratory Study on the Usefulness of Intellectual Capital Information. Int. J. Accounting and Finance, Vol. 3, No. 2, pp. 177-192. https://doi.org/10.1504/IJAF.2011.043847

Park, Y. W., \& Shin, H. H. (2004). Board Composition and Earnings Management in Canada. Journal of Corporate Finance, Vol. No.10, pp. 431-457. https://doi.org/10.1016/S0929-1199(03)00025-7

Peasnell, K., Pope PF, \& Young, S. (2005). Board Monitoring and Earnings Management: Do Outside Directors Influence Abnormal Accruals? Journal of Business Finance \& Accounting, Vol. 32, No. 7 \& 8, pp. 1311-1346. https://doi.org/10.1111/j.0306-686X.2005.00630.x

Peecher, M. E., Schwartz, R., \& Solomon, I. (2007). It's All about Audit Quality: Perspectives on Strategic-System Auditing. Accountings, Organizations and Society, Vol. 32, pp. 463-485. https://doi.org/10.1016/j.aos.2006.09.001

Rathke, A.A., Santana, V., Lourenço, I.M., \& Dalmácio, F.Z. (2016). International Financial Reporting Standards and Earnings Management in Latin America. RAC Rio de Janeiro, Vol. 20, No. 3, pp. 368-388. https://doi.org/10.1590/19827849rac2016140035

Riyadi, A., Utami, W. \& Nugroho, L. (2018). Potential Big Bath Accounting Practice in CEO Changes (Study on Manufacturing Companies Listed in Indonesia Stock Exchange). International Journal of Accounting and Finance Studies, Vol. 1, No. 2, pp. 202-215. https://doi.org/10.22158/ijafs.v1n2p202

Rudd, K. (2009). The Global Financial Crisis. The Monthly, February, pp. 20-29.

Rusmin, R., Scully, G., \& Tower, G. (2013). Income smoothing behaviour by Asian transportation firms. Managerial Auditing Journal, Vol. 28 No. 1, pp. 23-44. https://doi.org/10.1108/02686901311282489

Salleh, Z., Stewart, J., \& Manson, S. (2006). The Impact of Board Composition and Ethnicity on Audit Quality: Evidence from Malaysian Companies. Malaysian Accounting Review. Vol. 5, No. 2, pp. 61-83.

Sekaran, U. (2003). Research Methods for Business a skill building approach (4 $\left.{ }^{\text {th }} e d n\right)$. Canada: John Wiley and Sons, Inc.

Siregar, S., \& Utama, S. (2008). Type of Earnings Management and the Effect of Ownership Structure, Firm Size and Corporate Governance Practices: Evidence from Indonesia. The International Journal of Accounting, Vol. 43, pp. 1-27.

https://doi.org/10.1016/j.intacc.2008.01.001 
Sun, L., \& Rath, S. (2012). Pre-Managed Earnings Benchmarks and Earnings Management of Australian Firms. Australasian Accounting, Business and Finance Journal, Vol. 6, No. 1, pp. 29-55.

Thomson. Vaus, D. D. (2002). Analyzing social science data: 50 key problems in data analysis. London: SAGE Publications Ltd.

Wan Mohammad, W. M., Wasiuzzaman, S. \& Salleh, M. Z. (2016). Board and audit committee effectiveness, ethnic diversification and earnings management: a study of the Malaysian manufacturing sector. Corporate Governance, Vol. 16 No. 4, pp. 726746.

https://doi.org/10.1108/CG-06-2015-0085

Wasiuzzaman, S., Sahafzadeh, I. \& Nejad, N. R. (2018). Prospect theory, industry characteristics and earnings management: A study of Malaysian industries. Review of Accounting and Finance, Vol. 14 No. 3, pp. 324-347.

https://doi.org/10.1108/RAF-07-2014-0075

Watts, R.L. and Zimmerman, J.L. (1978). Towards a Positive Theory of the Determination of Accounting Standards. The Accounting Review, 53, 112-134.

World Bank (2009). Malaysia Economic Monitor: Repositioning for Growth, November.

World Bank Group Report (2018). Retrieved February 4, 2019, available at: https://data.worldbank.org/indicator/BX.KLT.DINV.WD.GD.ZS

Yoon, S., \& Miller, G. (2008). Cash from Operations and Earnings Management in Korea. The International Journal of Accounting, Vol. 37, pp. 395-412. https://doi.org/10.1016/S0020-7063(02)00193-0 